\title{
NANCY FRASER'S THEORY OF JUSTICE AS A CONTRIBUTION TO THE ANALYSIS OF AFFIRMATIVE ACTION POLICIES IN BRAZILIAN HIGHER EDUCATION
}

\section{ORIGINAL ARTICLE}

GUIMARÃES, Matheus De Oliveira ${ }^{1}$

GUIMARÃES, Matheus De Oliveira. Nancy Fraser's theory of justice as an contribution to the analysis of affirmative action policies in Brazilian higher education. Revista Científica Multidisciplinar Núcleo do Conhecimento. 04 year, Ed. 11, Vol. 01, pp. 22-38. November 2019. ISSN: 2448-0959, Access link in: https://www.nucleodoconhecimento.com.br/education/theory-of-justice

\section{SUMMARY}

This article seeks the presentation of the formulation of social justice appointed by the American political philosopher Nancy Fraser through which she interprets the social scenario today from the binomial recognition-redistribution. We will present theoretical arguments that may be of interesting value for the analysis, interpretation and evaluation of Brazilian educational policies directly linked to the theme of affirmative action policies. From the presentation of the Frasean theory about social justice and recognition, we seek to relate this thought, in an panoramic way, with the affirmative actions aimed at higher education implemented in Brazil - especially from the decade of 1990. To this end, nancy fraser's main arguments are demonstrated, for which justice today requires both the redistribution of social goods and wealth and cultural-

${ }^{1} \mathrm{PhD}$ student in The Right to Education and Educational Policies from the Graduate Program in Education of the Pontifical Catholic University of Minas Gerais (PucMinas). Master's degree in Education, linked to the research line Diversity, Inclusion and Educational Practices, by the Federal University of Ouro Preto (UFOP). He holds a degree in Law (UFOP), Philosophy (ICSH) and Pedagogy (FGD), specializing in Pedagogical Practices (UFOP) and Public Policy Management (UFOP). 
valorativo recognition of differences. Finally, the theoretical relationship between affirmative actions and frasean theory is established.

Keywords: affirmative actions, higher education, social justice, Nancy Fraser, race, redistribution-recognition.

\section{INTRODUCTION}

The Brazilian Constitution of 1988, in its article 206, item I, and the Brazilian Education Guidelines and Bases Act of 1996, in article 3, item I, establish that teaching must be provisioned respecting the principle of equal conditions. In line with this constitutional precept, educational policies began to be formulated and implemented with the purpose of reducing the social inequalities that have prevailed in the history of Brazil discriminating against various segments of society.

In the last two decades, with regard to the treatment of racial theme in Brazil, significant changes have occurred in the country that have been producing intense transformations in society. In this context, affirmative actions are included, understood as initiatives to promote social inclusion and, at the same time, singular aspects of groups and individuals are valued.

The connection between the discussions of Education, Law and Political Sciences with themes related to issues of redistribution and recognition - and specifically with regard to race - are significantly based on its unquestionable emphasis on the understanding and coping with inequalities in the social context, both in power relations and knowledge - inelutably interconnected (APPLE; BALL; GANDIN, 2013; GILLBORN; LADSON-BILLINGS, 2013; APPLE, 2017). Despite many's understanding of a supposed epiphenomenal character of what would eventually concern discussions about class and capitalism, it is essential to understand the relatively autonomous strength of race issues and the importance of focus on the particularities of daily life of those who live such situations (APPLE, 2017). 
In this sense, with the need to provide access (and permanence) to higher education to those who have neglected their chances of educational education, Brazilian public policies have been seeking a late universalization of higher education and, possibly despite the intended, they end up in line with the loss of the quality of teaching without effectively democratizing access. Although in the last two decades educational indicators have improved for all teaching ranges and in all social groups, severe racial inequalities are still observed - especially in the earliest stages (HEILBORN; ARAÚJO; BARRETO, 2010).

Despite the debate on affirmative action policies has focused, especially since the last decade, strongly on the quota system for public universities, the state's actions involve actions that go beyond quotas - with characteristics and differentiated scope.

Although it is possible to affirm that in the government Fernando Henrique Cardoso there were already federal initiatives aimed at the black population, the analysis of the documents of the period reveals that the discursive strategy and the policy of said government was to promote recognition without investments in the redistributive aspect, although inequality was the main justification for the policies of valuing the black population (LIMA, 2010).

The beginning of lula's administration in 2003 marks a dense change in policies with a racial perspective. As Lima (2010) states, until then the state's relationship with the Black Movement was of exteriority, basically constituting social actors as plaintiffs and with little insertion in the government apparatus. In lula's government, this relationship becomes from the incorporation, in its frameworks, of black representatives (giving greater visibility to the demands of the movement).

The fact is that the theme of higher education is certainly the one that mobilizes the most public debate on affirmative actions - especially with regard to the implementation of quota policies in public higher education institutions and analyses on students quota holders. However, as Lima (2010) states, the marked social reaction to quota policy did not have the same repercussion when the government implemented 
a program of affirmative actions in the private system - responsible for more than $80 \%$ of enrollment in Brazilian higher education .

The main public policies of the federal scope with racial cutout in education are organized today both in the sphere of cultural recognition and in that of redistribution. In Brazil, in addition to the infamous quota policy (often mistakenly understood as a synthesis of affirmative actions), PROUNI (University For All Program), through which the Federal Government offers scholarships (integral and for low-income students so that they can study in private colleges; fies (Student Financing Fund), a program of the Ministry of Education aimed at financing the undergraduate education of students enrolled in non-free institutions; and the PBP (Permanence Scholarship Program), a financial aid (offered by the Federal Government to low-income students in federal public universities and to students with full scholarships from PROUNI) that aims to minimize social inequalities and contribute to the permanence and graduation of undergraduate students in a situation of socioeconomic vulnerability.

Of these policies, Prouni is, of course, the most redistributive affirmative action of greater impact in the history of higher education in the country. Created in 2004, under Lula, by Provisional Measure 213/2004, Prouni was institutionalized in 2005 by Law $11,096 / 2005$. This program aims to grant full and partial scholarships to low-income students in undergraduate and sequential courses of specific training in private institutions of higher education. Tax exemptions are offered to institutions anuuídes to the Program.

Corroborating the idea of truncated democratization of access to higher education from affirmative actions, Pereira predicts, referring indirectly to Prouni's results:

[...] the private sector in Braz[responde]il for $88 \%$ of the offer of vacancies and for $71 \%$ of enrollment, making it one of the largest in the worl[...]d. With the help of the private network, the offer of vacancies for higher education today covers $86 \%$ of high school graduates. [Contudo][...]only $10 \%$ of young people aged eighteen to twenty-four years are attending it (2009, p. 45). 
Pereira (2009) adds that idle vacancies in private HEl were, before the implementation of Prouni, at $49.5 \%$ - while in the federal HEls this rate was $0.9 \%$ and, in the state, $4.7 \%$.

On the policies of expansion of higher education, Pereira informs:

The economic scenario we are experiencing is demonstrating that the effects of educational democratization do not lead to social democratization, but that they can produce new and more painful inequalities. (2009, p. 46).

And it is exactly as a proposal for the study of this complex context that indicates the analysis of the theorizations presented by Nancy Fraser (2008, 2003, 2002, 2000, 1997). Would affirmative actions aimed at democratising the access and permanence of minorities in higher education effective for the promotion of social transformation? From an economic point of view, would they be the same effective? And what are your impacts on the field of cultural-valorising recognition of your target audience?

It is not intended, in this text, conclusive answers to these questions. However, it is believed that the understanding of frasean arguments in this context is of interesting value for this analysis.

\section{ECONOMIC-DISTRIBUTIVE POLICIES X CULTURAL VALUATION} POLICIES: NANCY FRASER'S THEORIZATIONS ON THE DILEMMA REDISTRIBUTION-RECOGNITION AS $A^{[2]}$ SUBSIDY FOR THE INTERPRETATION OF AFFIRMATIVE ACTION POLICIES IN BRAZILIAN HIGHER EDUCATION

Nancy Fraser $(2008,2003,2002,2000,1997)$ points to the struggle for recognition as something that becomes, in strides, the paradigmatic form of political conflict since the end of the last century. According to Fraser $(2008,2003,2002,2000,1997)$, the demands for recognition of the difference fuel the struggles of groups mobilized under different flags - nationality, ethnicity, race, gender and sexuality. Consequently, group identity goes beyond, in these conflicts (called post-socialists), class interest itself as 
the main means of political mobilization: " cult[a]ural domination supplants exploitation as fundamental injustice. And cultural recognition takes the place of socioeconomic redistribution as a remedy for injustice and the goal of political struggle" (FRASER, 2008, p.11, translation of mine).

However, this is not all - since the struggles for recognition develop in a world of exacerbated material inequality - especially in southern countries.

In this context, in his theorizations, Fraser $(2008,2003,2002,2000,1997)$ raises some questions that will outline his debate on the dilemmas of justice:

How, then, should we see the eclipse of a socialist imaginary centered on terms such as interest, exploration and redistribution? And what should we do with the emergence of a new political imagery centered on notions of identity, difference, cultural domination and recognition? Does this yaw represent a lapse of false consciousness? Or, instead, would it be a way to compensate for the cultural blindness of a Marxist paradigm put to disrepute by the collapse of Soviet Communism? (FRASER, 2008, p.11, translation of mine, author griffins).

Categorically, Fraser $(2008,2003,2002)$ states that none of these positions would be appropriate, characterizing them as "too comprehensive and without nuances". Rather than simply endorsing or rejecting what would be simple ton in identity politics, it should be considered that there is an intellectual and practical challenge ahead: that of developing a critical theory of recognition that identifies and assumes the defends only those versions of the cultural policy of difference that can be combined consistently with the social equality policy (FRASER, 2008, p. 11-12).

In formulating this project, Fraser (2008) states that justice today requir es both redistribution and recognition, proposing to examine the relationship between the two. This, according to the author, would mean, in part, thinking about how to conceptualize cultural recognition and social equality in a way that both sustain themselves - rather than annihilating themselves (since there are several competing conceptions between them). Moreover, it would also mean theorizing about the means through which economic deprivation and cultural disrespect intertwine and support each other concomitantly. In this sense, moreover, for the author, justice also demands that the 
political dilemmas that arise should be clarified when we try to combat both injustices at the same time (FRASER, 2008, p. 12).

Fraser claims, as one of his purposes:

(...) two political problems that are now dissociated from each other. Only with the integration between recognition and redistribution will we reach a conceptual framework appropriate to the demands of our era (FRASER, 2008, p.12, translation of mine).

Two generic modes of understanding injustice are presented by Fraser (2008, p. 1318).

The first would be the one that refers to economic injustice - which, according to it, is rooted in the economic-political structure of society (exploitation, economic marginalization and deprivation) and whose conceptualization of its nature has already been undertaken, through great effort, by egalitarian theorists (FRASER, 2008, p. 1314).

The second way to understand injustice, according to Fraser (2008), is cultural or symbolic, deepening injustice in the social patterns of representation, interpretation and communication - the examples of which, according to the author, include cultural domination (concerning submission to patterns of interpretation and communication associated with another culture, unrelated and/or hostile to its own); concealment (relating to the invisibilization by the effect of communicative, interpretive and representational practices consented by the culture itself); and disrespect (characterized by defamation and routine disqualification in stereotyped public cultural representations and/or in the interactions of everyday life) (FRASER, 2008, p. 14).

However, despite the distinctions between these two forms of injustice (socioeconomic and cultural), Fraser $(2008,2003,2002,2000)$ states that both are markedly present in contemporary societies. Both are rooted in processes and practices that promote disadvantages to some groups compared to others. In this sense, both one and the other form of injustice must be remedied - albeit in different ways. 
For Fraser $(2008,2003,2002,2000)$, the remedy for economic injustice would be some kind of political-economic restructuring that could involve income redistribution, reorganization of the division of labor, democratic investment controls or transformation of other basic economic structures. The political philosopher attributes to this set of remedies for economic injustice the generic term redistribution.

In contrast, according to the author, the remedy for cultural injustice would be some kind of cultural or symbolic change. This could involve valuing the disrespected identities (as well as the cultural products of the defamed groups), the positive appreciation of cultural diversity, and, more radically, could encompass a comprehensive transformation of social standards representation, interpretation and communication, in order to transform the meaning of the self and of all people. Fraser $(2008,2003,2002,2000)$ gives this set of remedies for cultural injustice the term generic recognition.

For the author (FRASER, 2008), when dealing with collectivities that approach the ideal type of the exploited class, distributive injustices are faced that lack redistributive remedies (whose logic would be to promote homogenization and consequent mischaracterization of groups). When, in turn, we deal with collectivities that approach the ideal type of sexuality despised, for example, negative discrimination injustices are faced that need recognition remedies (whose logic, in turn, would be the valorization of the group from the recognition of their specificities). However, as it moves away from the ends, things become blurred and differentiation becomes much more complex and delicate. According to Fraser (2008), when considering collectivities located in the intermediate region of the conceptual spectrum, there are hybrid types that mix characteristics of the exploited class with characteristics of despised sexuality. These collectivities are called, as the author predicts, bivalent. They differ as collectivities both due to the political economic structure and the cultural-valorative structure of society:

These bivalent (oppressed or subordinated) collectivities suffer injustices that simultaneously date back to the political economy and culture. In short, as Fraser informs, these collectivities may suffer from poor socioeconomic distribution and cultural disregard so that none of these injustices is, in itself, an indirect effect of the 
other - but both primary and co-original. In this case, neither redistribution drugs nor those of recognition alone would be sufficient. Fraser states categorically: "bivalent collectivities lack both" (F[redistribuição e reconhecimento]RASER, 2008, p. 23, my translation).

Depending on Fraser, gender and race are paradigms of bivalent collectivities. Although they have unshared particularities among themselves, both cover economic dimensions and cultural-valorative dimensions: "gender and race, therefore, imply both redistribution and recognition" (FRASER, 2008, p. 23, translation of mine).

Thus, according to Fraser (2008, p. 25, my translation), "ra[...]ce is a bivalent mode of collectivity".

On the one hand, the fight against racism resembles the class, being a structural principle of the political economy. In this respect, race structures the capitalist division of labor. Low-paid, low-status occupations, those boring, dirty and domestic are disproportionately occupied by blac ${ }^{[3]} \mathrm{ks}$, while those best-paid occupations, with higher status, white colar, professionals, techniques and are mostly occupied by whites.

In addition, according to the author $(2008,2003,2002,2000,1997)$, race also structures access to the formal labor market, constituting vast segments of the black population as a subclass (disregarded even for the holding its elf) and excluded from the system Productive. As a result, there is a political-economic structure that engenders modes of exploitation, marginalization and deprivation marked specifically by race: "this structure constitutes race as an economic-political differentiation ended with certain characteristics" (2008, p. 26, my translation).

In this respect, according to the author (2008), racial injustice appears as a kind of distributive injustice that calls for redistributive compensation. Thus, in a very similar way to class, racial justice requires the transformation of the political economy to eliminate this racialization. And the logic of the remedy is similar to the logic related to the class: "it's about making race out of business" (FRASER, 2008, p. 26, my translation). If race is nothing more than an economic-political differentiation, justice 
requires, as Fraser says $(2008,2003,2002,2000)$, that it be abolished as a criterion of differentiation - in this sense.

However, as the author said when dealing with gender, race, as well as that, is not just economic-political. The breed also has cultural-valorative dimensions that insert it into the universe of recognition, also encompassing elements more similar to sexuality than with the class (FRASER, 2008, p. 26).

As Fraser (2008) points out, a basal aspect of racism is Eurocentrism characterized by the authorized construction of standards that favour the traits associated with branquitude. To this, cultural racism is added, characterized, in turn, by the widespread disqualification of things encoded as black, brown or yellow (p. 26).

As in the case of gender, these damages are injustices of recognition and, therefore, the logic of the remedy is also to grant positive recognition to a specifically devalued group.

Fraser $(2008,2003,2002,2000,1997)$ thus points to race as a bivalent mode of collectivity, with an economic-political and other cultural-valorative face - both faces intertwining to strengthen each other, dialectically - even more so because the racist and Eurocentric cultural norms are institutionalized in the state and in the economy, while the economic disadvantage suffered by blacks restricts their voice.

To compensate for racial injustice, political economy and culture are moved. But, as evidenced by the author when dealing with gender, the bivalent character of the race is also the source of a dilemma.

Fraser $(2008,2003,2002,2000)$ states that gender and race are therefore dilemmatic modes of collectivity. Unlike class, which occupies one end of the conceptual spectrum presented by the author, and sexuality, which occupies the other tip, gender and race are bivalent, being implicated simultaneously in the redistribution policy and in the politics of the Recognition. 
But how could differentiation be dissolved at the same time and the specificity of a scorned collectivity be dissolved?

After presenting the dilemma of redistribution-recognition in a seemingly intractable way and of assuming that redistributive remedies for economic-political injustice always differentiate social groups while recognition remedies for cultural-valorising injustice always highlight the differentiation of the social group, Fraser (2008, p. 28) proposes to examine alternative conceptions of redistribution - on the one hand - and recognition - on the other.

By affirmative remedies for injustice, Fraser understands those aimed at correcting unequal effects of social arrangements without the underlying structure that engenders them (2008, p. 28).

By transformative remedies, in contrast, the author comprises those focused on correcting unequal effects by remodeling the underlying gerativa structure $(2008, p$. 28).

In terms of the author, the fundamental point of contrast between affirmative remedies and transformative remedies for injustice is "terminal effects vs. processes that produce them. It is not gradual change vs. apocalyptic change" (FRASER, 2008, p. 28, my translation).

Fraser (2008) explains this distinction, first, in the case of remedies for cultural injustice. According to the author, the affirmative remedies for such injustices are associated with what she calls "mainstream multiculturalism" - a kind of multiculturalism that proposes to compensate for disrespect by revaluation of group identities unfairly devalued (while leaving intact the contents of these identities and the group differentiations underlying them). In contrast, transformative remedies are associated with deconstruction, compensating for disrespect through the transformation of the underlying cultural-valorative structure. As Fraser states, destabilizing existing group identities and differentiations, these remedies would not 
only raise the self-esteem of members of recurrently disrespected groups, but would also transform the sense of belonging and affiliation of all (p. 28-29).

For the author, the issue is not about the dissolution of all difference in a unique and universal human identity, but rather the maintenance of a field of multiple differences, not binary, fluid, always on the move:

While affirmative recognition remedies tend to promote existing group differentiations, transformative recognition remedies tend in the long run to destabilize them in order to make room for future regroupings (FRASER, 2008, p. 30, my translation).

Similar distinctions apply to remedies for economic injustice. As Fraser says (2008, 2003, 2002), affirmative remedies for this type of injustice are historically associated with the liberal welfare state, seeking, through them, compensation for terminal poor distribution (while leaving most of the underlying economic-political structure). Transformative remedies, against, historically associate themselves with socialism, seeking to compensate for unfair distribution through the transformation of the existing economic-political structure.

Fraser states that an approach aimed at compensating distribution injustices may end up creating recognition injustices (2008, p. 31).

Affirmative redistribution presupposes a universalistic conception of recognition (equal moral value of people; entitled by Fraser $(2008,2003,2002)$ as a formal commitment to recognition). However, the practice of affirmative redistribution, if prolonged, tends to set in motion a secondary dynamics of stigmatizing recognition that contradicts its own formal commitment to universalism ${ }^{[4]}$. The author (2008), contrasting this logic with transformative remedies for class distributive injustices, predicts that they combine universalist social welfare programs, high taxes, macroeconomic policies aimed at creating full employment, a vast non-market public sector, significant public and/or collective properties, and democratic decisions regarding basic socioeconomic priorities. Transformative redistribution remedies tend to dissolve class differentiation, reducing social inequality without creating stigmatized classes of vulnerable people seen as beneficiaries of special generosity. Fraser states that these remedies tend to 
promote reciprocity and solidarity in recognition relationships, thus being able to address compensation for redistribution injustices to help, too, compensate for certain injustices of recognition (2008, p.31-33)

Fraser (2008) states that, like affirmative redistribution, transformative redistribution (in general) presupposes a universalistic conception of recognition: equal moral value of people. However, unlike affirmative redistribution, the practice of transformative redistribution tends not to dissolve this conception.

From this discussion, after considering only the typical cases-pure ideas at both ends of the conceptual spectrum, and contrast the divergent effects of affirmative and transformative remedies to rooted distributive injustices economically - on the one hand - and those of culturally rooted recognition - on the other - it is seen that: 1 . affirmative remedies generally tend to promote group differentiation, while transformative remedies tend to destabilize and blur this differentiation; and 2 . Affirmative redistribution remedies can engender a protest of contempt, while transformative redistribution remedies can help offset some forms of non-recognition. In this sense, Fraser $(2008,2003,2002)$ suggests a way to reformulate the redistribution-recognition dilemma.

However, in concluding this discussion, Fraser raises the questioning:

[...] with regard to groups submitted to both types of injustice, what would be the combination of remedies that would work best to minimize (if not to eliminate for good) the mutual interferences that arise when seeking redistribution and recognition to the same time? (2008, p. 33, my translation).

And that should still be problematized. 


\section{FINAL CONSIDERATIONS: THE CONTEXTUALIZATION OF THE FRASEANO DEBATE TO THE REALITY OF HIGHER EDUCATION IN BRAZIL}

It is affirmed that Brazil, because it is characterized by numerous inequalities, of different orders, is marked as a paradigmatic model to think about the application of the phraseane theory. In this sense, Fraser's theorizations are proposed for the analysis of the Brazilian educational scenario.

As Ferreira (2010) claims, modernity, upon arriving in Brazil, found a country with brands of conservatism and traditionalism - a situation that, in a way, remains to this day in various social sectors. In Brazil, prejudice and racial exclusion have taken place (and still conserve, to some extent) in a veiled, uninstitutionalized and openly recognized way. This compromises, in many cases, the processes of taking action by the government. Actions such as affirmative action policies are repeatedly seen as an affront to equal opportunities - even if inequality, segregation and prejudice are visible (FERREIRA, 2010).

It is in this sense that the performance of the public authorities with a view to reducing social inequalities can be understood from Fraser's theorizations (2008, 2003, 2002, 2000) on recognition and redistribution. It is essential that redistribution and recognition policies do not contradict each other and, in addition, be guided by mutual respect (APPLE, 2017, p. 32).

Affirmative action policies are part of Fraser $(2008,2003,2002)$, as a remedy against social injustices. However, as Ferreira (2012) predicts, an important point to be considered in this discussion refers to the fact that, still from a frasean perspective, affirmative actions would not be absolute guarantees in order to positively modify the structure that generates inequalities. This is because, perhaps, a priori, they only recognize the need for distribution to historically impaired groups, but do not necessarily solve the structural impasses that generate such inequalities. The expectation would be that those benefited by these policies could - on a large scale 
and in the long term - transmit their results of socioeconomic and cultural growth in an intergenerational way so that their descendants no longer need policies of this kind to remain on the rise or achieve income and status levels similar to those of the population who have historically received these rights in Brazil.

\section{REFERENCES}

APPLE, Michael W. A educação pode mudar a sociedade?. Petrópolis: Vozes, 2017.

APPLE, Michael W.; BALL, Stephen J.; GANDIN, Luís Armando. Mapeamento da sociologia da educação: contexto social, poder e conhecimento. In: Sociologia da Educação: análise internacional. Michael W. Apple; Stephen J. Ball; Luís Armando Gandin (orgs.). Porto Alegre: Penso, 2013.

LIMA, Márcia. Ações afirmativas no governo Lula. In: Revista Novos Estudos. 2010.

FERREIRA, Wallace. Justiça e reconhecimento em Nancy Fraser. Teresina: Jus Navigandi, 2012.

FRASER, Nancy. From Redistribution to Recognition? Dilemmas of Justice in a "Postsocialist" Age. In. Adding Insult to Injury. Nancy Fraser debates her critics. Edinburgh: Verso, 2008.

Justice Interruptus: Critical Reflections on the "Postsocialist" Condition. London: Routledge, 1997.

Redistribuição ou reconhecimento? Classe e status na sociedade contemporânea. In: Interseções - Revista de Estudos Interdisciplinares. UERJ, ano 4, n.1, 2002.

Recognition without Ethics? Theory, Culture \& Society, v. 18, p. 21-42, 2001.

Da redistribuição ao reconhecimento? Dilemas da justiça na era pós-socialista. In: Democracia hoje: novos desafios para a teoria democrática contemporânea. Jessé Souza (org.). Brasília: Editora Universidade de Brasília, 2000. 
FRASER, N.; HONNETH, A. Redistribution or recognition?: a political philosophical exchange. London; New York: Verso, 2003.

GILLBORN, David; LADSON-BILLINGS, Gloria. Educação e Teoria Racial Crítica. In: Sociologia da Educação: análise internacional. Michael W. Apple; Stephen J. Ball; Luís Armando Gandin (orgs.). Porto Alegre: Penso, 2013.

HEILBORN, M. L.; ARAÚJO, L.; BARRETO, A. (Orgs). Gestão de Políticas Públicas em Gênero e Raça: GPP-GeR, Módulo I. Rio de Janeiro: CESPE; Brasília: Secretaria de Políticas Públicas para as Mulheres. 2010.

PEREIRA, Elisabete Monteiro de Aguiar. A universidade da modernidade nos tempos atuais. In: Revista Avaliação, v. 14, n. 1, p. 29-52. Campinas, 2009.

ZONINSEIN, Jonas; FERES JÚNIOR, João. Ação Afirmativa e Desenvolvimento. In: FERES JÚNIOR, João \& ZONINSEIN, Jonas (Orgs.). Ação Afirmativa e Universidade: experiências nacionais comparadas. Brasília: Editora Universidade de Brasília, 2006.

2. Toma-se, aqui, como referência principal para a análise que se propõe, a seguinte obra: FRASER, Nancy. From Redistribution to Recognition? Dilemmas of Justice in a "Postsocialist" Age. In. Adding Insult to Injury. Nancy Fraser debates her critics. Edinburgh: Verso, 2008.

3. "People of color", nos termos de Fraser.

4. Nos termos de Fraser, essa dinâmica secundária (estigmatizante) pode ser entendida como o efeito de reconhecimento prático da redistribuição afirmativa (2008, p. 31-32).

Submitted: October, 2019.

Approved: November, 2019. 